E-ISSN : 2549-6581

DOI: 10.21776/ub.JOIM.2019.003.03.5

Artikel Hasil Penelitian

Diterima : 19 Juli 2019

Direview : 16 Oktober 2019

Dimuat : Desember 2019 - Maret 2020

\title{
Analisis Faktor Determinan Perilaku Ibu Dalam Kehamilan Terhadap Berat Badan Bayi Di Rumah Sakit Umum Daerah Simeulue Tahun 2018
}

\author{
Ira Purnama Sari ${ }^{1 *}$, Raziya Begum Suroyo ${ }^{2}$, Aida Fitria ${ }^{2}$ \\ $\left.{ }^{*}\right)$ S2 Kesehatan Masyarakat, Fakutas IImu Kesehatan Masyarakat, Institut Kesehatan Helvetia, \\ Medan, Email: ira.purnamasari17@gmail.com , Tlp: 085261912642 \\ ${ }^{2}$ Fakultas Kesehatan Masyarakat, Fakutas IImu Kesehatan Masyarakat, Institut Kesehatan Helvetia, \\ Medan, Email: aidafitria@helvetia.ac.id; raziabegum@helvetia.ac.id
}

\begin{abstract}
Introduction, Data which is obtained from Perinatology Medical Record General Hospital Simeulue Regency in 2016 the babies birth were 562 babies by 96 cases low born babies weight (17\%) and increased in 2017 found 571 babies live born with 179 low weight babies born (31,3\%). According to Aceh Health Profile in 2016 AKB with babies born 11 per 1000. This was quantitative with analytic survey and cross-sectional design. The population in this research was all mother who had babies on August 2018. There are 48 mothers and all population was as the sample. Data collection techniques, were primary ,secondary and tertiary. The Data analysis was using univariat, bivariat dan multivariat by testing Chisquare and double logistic binary. As the result, Research result showed that big part respondent of low knowledge was 26 person (54,2\%), high education was 25 person(52,1\%), low socioeconomic was 25 person (52,1\%), ANC test quality with under standard was 27 person (56,3\%), good-family supporting was 28 person(58,3\%), and less-treatment was 19 orang $(39,6 \%)$. It is assumed that there is correlation between treatment of mother who had babies with born babies body weight and no influence between education (sig 0,305), Family supporting (sig 0,151), there is influence between socioeconomic (sig 0,035), ANC test quality (sig 0,006), knowledge (sig 0,002) toward mother behaviour in pregnancy. It is suggested that the medical workers in Simeulue Regency General Hospital were being more active in taking care women pregnant in order to do consultation and check up to medical workers.
\end{abstract}

Key word: Maternal behavior, pregnancy, baby's weight

\begin{abstract}
ABSTRAK
Pendahuluan, Data Rekam Medik yang diperoleh dari Perinatalogi tahun 2016 jumlah kelahiran hidup sebanyak 562 bayi dengan kasus berat bayi lahir rendah sebanyak $17 \%$ dan meningkat pada tahun 2017 dengan jumlah kelahiran hidup 571 bayi dengan BBLR sebanyak 31,3\%. Menurut Profil Kesehatan Aceh tahun 2016 presentase AKB tertinggi terdapat di Kabupaten Simeulue sebesar 21/1000 kelahiran hidup dan AKB terendah terdapat di Kabutaen Pidie Jaya sebesar 2/1000 kelahiran hidup. Metode, Desain penelitian yang digunakan adalah cross-sectional. Populasi dalam penelitian ini seluruh ibu bersalin pada bulan Agustus tahun 2018 sebanyak 48 ibu dan semua populasi dijadikan sebagai sampel. Teknik pengumpulan data adalah primer, sekunder dan tersier. Analisa data yang digunakan yaitu uji regresi binary logistic. Hasil penelitian menunjukkan pengetahuan
\end{abstract}


memiliki sig $0,002<\alpha=0,05$, pendidikan memiliki sig $305>\alpha=0,05$, sosial ekonomi memiliki sig 0,092 > $\alpha=0,05$, kualitas pemeriksaan ANC memiliki sig 0,006 $<\alpha=0,05$, dukungan keluarga memiliki sig 0,109 $>\alpha=0,05$. Kesimpulan dalam penelitian ini ada pengaruh pengetahuan, kualitas pemeriksaan ANC terhadap berat badan bayi sedangkan variabel pendidikan, sosial ekonomi dan dukungan keluarga tidak memiliki pengaruh terhadap berat badan bayi. Disarankan kepada tenaga kesehatan agar lebih aktif menjaring ibu hamil untuk memeriksakan kehamilannya guna mencegah terjadinya bayi BBLR.

Kata Kunci : Perilaku lbu, kehamilan, Berat badan bayi

*Korespondensi: Ira Purnama Sari. Surel: ira.purnamasari17@gmail.com

\section{PENDAHULUAN}

Masa kehamilan merupakan masa - masa yang sangat membahagiakan bagi seorang istri, keinginannya bersama suami tercinta untuk memiliki anak akan segera terwujud. kelahiran anak diibaratkan sebuah kado spesial dari sang pencipta. Namun dibalik kebahagiaan tersebut tidak sedikit ibu hamil yang memiliki perasaan khawatir tentang kehamilan, mulai dari perubahan bentuk tubuh, terjadinya gangguan selama kehamilan, proses melahirkan yang menyakitkan, melahirkan bayi tidak sesuai dengan yang diingikan, dan terjadinya masalah pada berat lahir bayi yang tidak optimal (1).

Bayi adalah anak yang berusia 0 - 12 bulan. Bayi dapat di kelompokkan menjadi tiga yaitu bayi cukup bulan, bayi prematur dan bayi dengan berat lahir rendah (BBLR). Bayi cukup bulan adalah bayi yang termasuk dalam kelompok kelahiran normal, yaitu kelahiran bayi secara alami tanpa bantuan suatu alat apapun atau tanpa operasi, yang lahir dari usia kehamilan 37 minggu sampai 42 minggu dengan berat badan lahir 2500 gram sampai dengan 4000 gram, serta tidak ada kelainan congenital (cacat bawaan) yang berat. Bayi prematur adalah bayi lahir tidak cukup bulan. Adapun bayi berat lahir rendah (BBLR) atau low birth weight adalah bayi baru lahir yang berat badannya saat lahir kurang dari 2500 gram (2).

Pada saat dilakukan survey awal data yang diperoleh dari Rekam Medik
Perinatalogi Rumah Sakit Umum Daerah Simeulue tahun 2016 ditemukan jumlah kelahiran hidup sebanyak 562 bayi dengan kasus berat bayi lahir rendah sebanyak 96 bayi (17\%). Kasus ini meningkat pada tahun 2017 dengan ditemukan jumlah kelahiran hidup sebanyak 571 bayi dengan berat lahir rendah sebanyak 179 bayi $(31,3 \%)$. Sedangkan bayi dengan berat lahir > 2500 gram terdapat 466 (82,9\%) jiwa pada tahun 2016 dan menurun sebesar 392 (68,7\%) dari 571 kelahiran hidup periode januari sampai dengan desember pada tahun 2017 (3), (4).

Hal ini menunjukkan faktor faktor yang dapat memengaruhi berat bayi lahir adalah faktor lingkungan internal (umur ibu, jarak kelahiran, paritas, status gizi ibu hamil kadar hemoglobin, pemeriksaan kehamilan dan penyakit pada saat kehamilan), faktor lingkungan ekstertanal (kondisi lingkungan, asupan zat gizi, dan tingkat sosial ekonomi ibu hamil), faktor penggunaan sarana kesehatan yang berhubungan dengan frekuensi pemeriksaan kesehatan atau antenatal care (5).

Bayi yang sehat terlahir dari ibu yang sehat pula. pada saat hamil hendaknya ibu harus memiliki kesadaran tinggi untuk selalu menjaga dan memantau kondisi kesehatan dengan memeriksakan kehamilan secara teratur ke fasilitas kesehatan terdekat, memperhatikan asupan status gizi serta 
lebih aktif dalam mendiskusikan kondisi ibu kepada dokter maupun bidan. dengan demikian kesehatan ibu dan janin selalu terjaga selama kehamilan. Kurangnya pengetahuan dan informasi tentang kehamilan yang sehat dapat meningkatkan kejadian risiko tinggi pada kehamilan (1).

Umur ibu erat kaitannya dengan bayi lahir. kehamilan yang terjadi dibawah usia kurang dari 20 tahun akan beriko melahirkan bayi dengan berat lahir rendah. hal ini terjadi karena kurang matangnya alat reproduksi terutama rahim yang belum siap menerima beban selama proses kehamilan, anemia kehamilan, dan keracunan kehamilan karena alat reproduksi yang belum siap hamil disertai dengan anemia makin meningkatkan terjadinya keracunan kehamilan dalam bentuk preeklampsia atau eklampsiap sedangkan kehamilan pada usia lebih dari 35 tahun memiliki problem kesehatan seperti hipertensi, diabetes gestasione, plasenta previa, pendarahan akibat jaringan rongga dan otot panggul yang melemah dan kualitas seltelur berkurang sehingga mengakibatkan peluang terjadinya perkembangan janin tidak normal dan kasus bayi yang memiliki kelainan bawaan menjadi tinggi (1).

Kepercayaan sosial dan budaya yang kompleks di negara berkembang telah menempatkan perempuan pada posisi yang kurang menguntungkan. Di masyarakat di mana pernikahan dini umum terjadi, para remaja sering kali meninggalkan sekolah mereka karena hamil sebelum tubuh mereka sepenuhnya matang. Dengan kondisi kesehatan, tubuh yang belum matang, sumber daya dan dukungan yang tidak memadai sehingga ibu-ibu mudah ini sering kali gagal untuk mendapatkan berat badan yang cukup selama kehamilan dan merekapun rentan terhadap berbagai komplikasi yang bisa menempatkan diri dan bayi mereka pada resiko (6).

Status gizi merupakan ukuran keberhasilan dalam pemenuhan nutrisi untuk ibu hamil. Gizi ibu hamil merupakan nutrizi yang diperlukan dalam jumlah yang banyak untuk pemenuhan gizi ibu sendiri dan perkembangan janin yang dikandungnya. Penyebab kekurangan gizi pada ibu hamil karena konsumsi makanan yang tidak memenuhi syarat pemenuhan gizi. Tingkat pengetahuan yang rendah menyebabkan ibu tidak mengerti cara pemenuhan nutrisi yang dibutuhkan ibu hamil selama kehamilannya, ditambah lagi dengan staus gizi ibu hamil yang dipengaruhi oleh keadaan sosial ekonomi yang rendah dan kesehatan ibu hamil selama kehamilan terlebih lagi dengan beban pekerjaan yang berat pada perempuan desa menambah buruknya gizi dan kesehatan kaum perempuan. Kelahiran yang terlalu muda, terlalu rapat, terlalu banyak dan terlalu tua menambah buruknya kondisi kesehatan dan gizi ibu hamil yang merupakan salah satu faktor risiko terjadinya abortus, bayi lahir mati, dan bayi lahir dengan berat badan rendah (7).

Anak yang lahir dari ibu yang kurang gizi dan hidup dilingkungan miskin akan beriko mengalami kurang gizi dan mudah terkena infeksi, selanjutnya akan menghasilkan wanita dewasa yang kurang gizi pula. Indonesia sebagai salah satu negara berkembang yang memiliki peran penting dalam perekonomian dunia, menempati urutan ketiga sebagai negara dengan prevalensi BBLR tertinggi (11,1\%), setelah India $(27,6 \%)$ dan Afrika Selatan $(13,2 \%)$. Selain itu, Indonesia turut menjadi negara ke dua dengan prevalensi BBLR tertinggi di antara 
negara asean lainnya, setelah Filipina $(21,2 \%)(2)$.

Di seluruh dunia, setiap tahun diperkirakan 4 juta bayi meninggal pada tahun pertama kehidupannya dan dua pertiganya meninggal pada bulan pertama. Dua pertiga dari yang meninggal pada bulan pertama meninggal pada minggu pertama. Dua pertiga dari yang meninggal pada minggu pertama meninggal pada hari pertama. penyebab utama kematian pada minggu pertama kehidupan adalah komplikasi kehamilan dan persalian seperti asfiksia, sepsis dan komplikasi berat lahir rendah (8).

Diseluruh Indonesia dari seluruh kematian bayi, sebanyak 57\% meninggal pada masa bayi baru lahir (usia dibawah 1 bulan). setiap 6 menit terdapat 1 bayi baru lahir yang meninggal. Penyebab kematian bayi baru lahir di Indonesia adalah bayi berat lahir rendah (29\%), asfiksia (27\%), trauma lahir, tetanus neonatorum, infeksi lain dan kelainan congenital. Berdasarkan data yang diambil dari Dinas Kesehatan Kabupaten Simeulue pada tahun 2017 di dapati bahwa jumlah angka kematian bayi sebanyak 35 orang dengan uraian penyebab kematian sebagai berikut: asfiksia 9 orang $(22,8 \%)$, kelainan congenital 5 orang $(14,2 \%)$, sepsis 2 orang $(5,7 \%)$, diare 2 orang $(5,7 \%)$, dermatitis 1 orang $(3,3 \%)$, lain - lain 5 orang $(14,2 \%)$, sesak 2 orang $(5,7 \%)$, dan BBLR sebanyak 9 orang $(22,8 \%)$ (8), (9).

Faktor ibu sangat berhubungan dengan pertumbuhan janin. Saat hamil, minum-minuman keras dan merokok sebaiknya dihentikan. Karena alkohol dapat mengganggu tumbuh kembang janin, salah satunya adalah terjadi retardasi mental atau keterlambatan perkembangan mental contohnya anak idiot. Semakin banyak alkohol yang diminum, semakin tinggi risiko gangguan pada janin. Kebiasaan merokok saat hamil bisa menyebabkan kelahiran prematur dan kelainan letak plasenta serta dapat menyebabkan ketuban pecah dini sehingga memperlambat perjalan persalinan dan menyebabkan sudden infant death syndrome, yaitu sindrom kematian mendadak pada bayi (10).

Pemantauan kehamilan selama Antenatal Care sangat menentukan keberhasilan bagi kesehatan ibu hamil. Tujuan dari pemeriksaan Antenatal Care ini adalah untuk memantau berbagai kemungkinan gangguan patologis atau risiko tinggi yang bisa terjadi sehingga dapat diketahui secara dini dan mengambil langkah-langkah yang intensif. Faktor risiko tinggi adalah keadaan gangguan apapun selama kehamilan maupun nanti waktu bersalin yang dapat merupakan kondisi berbahaya baik kesehatan ibu hamil maupun janin yang akan dilahirkan seperti, prematur, bayi dengan berat lahir rendah dan gangguan yang dapat menimbulkan kematian prenatal (11).

Berdasarkan data yang diperoleh dari Profil Kesehatan Indonesia tahun 2015 diketahui angka kematian bayi di Indonesia saat ini 22,23 per 1000 kelahiran hidup. Sebanyak 19 per 1000 kelahiran hidup terjadi pada masa neonatal sejak lahir sampai usia 28 hari. Lebih dari tiga perempat dari kematian ini disebabkan oleh tiga penyebab utama yaitu kesulitan bernafas saat lahir atau asfiksia, infeksi dan komplikasi lahir premature dan berat badan lahir rendah (12).

Menurut Profil Kesehatan Aceh tahun 2016 diketahui AKB sebesar 11 bayi per 1000 kelahiran dan AKN di aceh 8 per 1000 kelahiran hidup. Presentase AKB tertinggi terdapat di Kabupaten Simeulue sebesar 21 per 1000 kelahiran 
hidup, diikuti bener meriah sebesar sebesar 20 per 1000 kelahiran hidup dan angka kematian bayi terendah terdapat di Kabutaen Pidie Jaya sebesar 2 per 1000 kelahiran hidup, diikuti Kabupaten Aceh Tenggara sebesar 3 per 1000 kelahiran hidup dan bayi dengan berat lahir rendah sebanyak 1.178 bayi $(21 \%)$ dari 5097 bayi yang lahir pada tahun 2015. Penyebab kematian ini dapat di cegah dengan memastikan setiap ibu melahirkan di damping oleh tenaga kesehatan yang terlatih (13).

Rumah Sakit Umum Daerah (RSUD) Simeulue adalah rumah sakit pemerintah satu-satunya yang ada di Kabupaten Simeulue, yang merupakan pusat rujukan persalinan dari seluruh persalinan ditingkat dasar sehingga pertolongan persalinan yang dilakukan merupakan rujukan dari puskesmas, bidan praktek swasta yang memunyai masalah dalam persalinan. berdasarkan survey awal tersebut ditemukan bahwa, ada ibu yang melahirkan dengan usia yang kurang dari 20 tahun dan lebih dari 35 tahun ada juga yang melahirkan dengan jumlah anak lebih dari 4, jarak kelahiran anak ibu yang terlalu dekat dengan anak yang sebelumnya serta gizi ibu yang tidak terpenuhi saat hamil dikarenakan sosial ekonomi yang rendah sehingga kebutuhan untuk membeli makanan yang berkualitas dan sehat tidak dapat tercukupi karena minimnya tingkat pendapatan keluarga dan sebagian besar ibu-ibu yang melahirkan bayi dengan berat lahir rendah jarang melakukan pemeriksaan antenatal care yang sesuai jadwal atau jika ada keluhan saja hal ini terjadi karena riwayat kehamilan yang sebelumnya tidak bersalah.

Berdasarkan uraian tersebut diatas maka dari itu peneliti tertarik melakukan penelitian dengan judul "Analisis Faktor Determinan Ibu
Terhadap Berat Bayi Lahir di Rumah Sakit Umum Daerah Simeulue Tahun 2018." Karena berat bayi lahir banyak berhubangan dengan meningkatnya resiko kesakitan dan kematian pada bayi.

Tujuan penelitian ini yaitu untuk mengetahui faktor yang mempengaruhi perilaku ibu dalam kehamilan terhadap berat badan bayi di Rumah Sakit Umum Daerah Simeulue Tahun 2018.

\section{METODE PENELITIAN}

Rancangan/Desain Penelitian

Jenis penelitian ini merupakan penelitian kuantitatif dengan desain survey analitik dengan rancangan cross-sectional, yaitu melakukan pengukuran atau pengamatan pada seluruh variabel terikat (dependent) dengan variabel bebas (independent) dilakukan dalam waktu yang sama (39).

Sumber Data

Sumber data pada penelitian ini meliputi data primer yang merupakan data umur responden, pengetahuan, pendidikan, jumlah pendapatan keluarga setiap bulannya, kualitas pemeriksaan ANC yang dilakukan oleh petugas kesehatan, dan berat badan bayi yang diperoleh dari hasil wawancara dengan responden.

Data sekunder meliputi jumlah Bayi Baru Lahir yang diperoleh dari data rekam medik perinatologi Rumah Sakit Umum Daerah Simeulue.

Data tertier diperoleh dari Profil Kesehatan Indonesia tahun 2015, jurnal peneliti sebelumnya, dan text book.

\section{Sasaran penelitian}

(Populasi/Sampel/Subjek Penelitian)

Populasi dalam penelitian ini adalah seluruh ibu dari bayi yang lahir hidup sebanyak 48 orang yang bersalin di RSUD Simeulue pada bulan Agustus Tahun 2018. Dan penentuan pengambilan sampel menurut Arikunto, sebagai berikut: apabilah kurang dari 100 lebih baik diambil semua hingga penelitiannya merupakan penelitian populasi.

Berdasarkan pendapat Arikunto tersebut, maka peneliti mengambil seluruh populasi dijadikan sampel sebanyak 48 
orang yaitu semua ibu dari bayi yang lahir hidup pada bulan Agustus tahun 2018 di RSUD Simeulue.

Pengembangan Instrumen dan Tehnik Pemngumpulan Data

Pengembangan instrumen penelitian berdasarkan pedoman penyusunan kuesioner penelitian karya Noto Atmodjo. Selanjutnya bentuk soal pertanyaan dan pernyataan disesuaikan dengan kerangka penelitian.

Tehnik Pengumpulan data terdiri dari:

a. Data primer dalam penelitian ini diperoleh langsung dari responden dan dikumpulkan melalui pengisian kuesioner.

b. Data sekunder diperoleh dari Rumah Sakit Umum Daerah Simeulue.

c. Data tertier diperoleh melalui data riset yang sudah dipublikasikan secara resmi oleh Kementerian Kesehatan RI.

\section{Teknik Analisis Data}

Teknik analisis data yang digunakan yaitu analisis univariat, bivariat dan multivariat. Analisis univariat digunakan untuk mendeskripsikan data yang dilakukan pada tiap variabel dari hasil penelitian. Data disajikan dalam tabel distribusi frekuensi. Analisis bivariat di lakukan untuk melihat hubungan masing-masing variabel bebas dengan variabel terikat. Dalam analisis bivariat ini, data variabel independen dan dependen dihitung secara bersama-sama yang dimasukkan dalam tabel silang. Uji statistik yang digunakan Chi-square dengan tingkat kepercayaan $95 \%(\alpha=0,05)$, apabila hasil perhitungan menunjukkan nilai $\mathrm{p}<\mathrm{p}$ value $(0,05)$ maka dikatakan $(\mathrm{Ho})$ ditolak dan $\mathrm{Ha}$ diterima, artiya kedua variabel secara statistik mempunyai hubungan yang signifikan. Analisis multivariat digunakan untuk melihat kemaknaan kolerasi antar variabel bebas (independent variable) dengan variabel terikat (dependent variable) di lokasi penelitian secara simultan dan sekaligus menentukan faktor - faktor yang lebih dominan berpengaruh. Untuk menguji data secara multivariat, peneliti menggunakan uji regresi linier berganda binary (logistic regression), dengan persamaan:

$$
\begin{gathered}
\operatorname{Ln} P / 1-P=C+B X 1+B X 2+B X 3+B X 4+ \\
B X 5
\end{gathered}
$$

\section{HASIL PENELITIAN}

Analisis Univariat

Berdasarkan tabel distribusi frekuensi dapat dilihat bahwa dari 48 responden, mayoritas frekuensi sosial ekonomi responden kategori rendah sebanyak 25 orang (52,1\%), minoritas frekuensi kategori tinggi sebanyak 23 orang $(47,9 \%)$. Dari 48 responden dapat dilihat bahwa mayoritas frekuensi kualitas ANC responden kategori sesuai standart sebanyak 21 orang $(43,7 \%)$, minoritas frekuensi kategori tidak sesuai standart sebanyak 27 orang (56,3\%). Dari 48 responden dapat dilihat bahwa mayoritas frekuensi pendidikan responden kategori tinggi sebanyak 25 orang $(52,1 \%)$, minoritas frekuensi kategori rendah sebanyak 23 orang $(47,9 \%)$. Dari 48 responden dapat dilihat bahwa mayoritas frekuensi pengetahuan responden dengan kategori kurang baik sebanyak 26 orang $(54,2 \%)$, minoritas frekuensi dengan kategori baik sebanyak 22 orang (45,8\%). Dari 48 responden dapat dilihat bahwa mayoritas frekuensi dukungan keluarga dengan kategori mendukung sebanyak 28 orang $(58,3 \%)$, minoritas frekuensi dengan kategori tidak mendukung sebanyak 20 orang $(41,7 \%)$. Dari 48 responden dapat dilihat bahwa mayoritas frekuensi perilaku responden dalam kehamilan dengan kategori baik sebanyak 29 orang $(60,4 \%)$, minoritas frekuensi dengan kategori kurang baik sebanyak 19 orang (39,6\%). Dari 48 responden dapat dilihat bahwa mayoritas frekuensi berat badan bayi responden dengan kategori $\geq 2500$ gram sebanyak 35 orang $(72,9 \%)$, minoritas frekuensi kategori $<2500$ gram sebanyak 13 orang $(27,1 \%)$. 
Tabel 1. Distribusi Frekuensi Berdasarkan Sosial Ekonomi, Kualitas Pemeriksaan ANC, Pendidikan, Pengetahuan, Dukungan Keluarga, Perilaku dan Berat Badan Bayi

\begin{tabular}{|c|c|c|}
\hline Variabel & $f$ & $\%$ \\
\hline \multicolumn{3}{|l|}{ Sosial Ekonomi } \\
\hline Tinggi & 23 & 47,9 \\
\hline Rendah & 25 & 52,1 \\
\hline \multicolumn{3}{|l|}{ Kualitas Pemeriksaan ANC } \\
\hline Sesuai standar & 21 & 43,7 \\
\hline Tidak Sesuai Standar & 27 & 56,3 \\
\hline \multicolumn{3}{|l|}{ Pendidikan } \\
\hline Tinggi & 25 & 52,1 \\
\hline Rendah & 23 & 47,9 \\
\hline \multicolumn{3}{|l|}{ Pengetahuan } \\
\hline Baik & 22 & 45,8 \\
\hline Kurang Baik & 26 & 54,2 \\
\hline \multicolumn{3}{|l|}{ Dukungan Keluarga } \\
\hline Mendukung & 28 & 58,3 \\
\hline Tidak Mendukung & 20 & 41,7 \\
\hline \multicolumn{3}{|l|}{ Perilaku } \\
\hline Baik & 29 & 60,4 \\
\hline Kurang Baik & 19 & 39,6 \\
\hline \multicolumn{3}{|l|}{ Berat Badan Bayi } \\
\hline$\geq 2500$ gram & 35 & 27,1 \\
\hline$<2500$ gram & 13 & 72,9 \\
\hline
\end{tabular}

Analisis Bivariat

Berdasarkan tabulasi silang antara sosial ekonomi dengan perilaku ibu dalam kehamilan, diketahui bahwa sosial ekonomi pada kategori rendah dengan perilaku kurang baik sebanyak 14 orang $(29,2 \%)$ dan sosial ekonomi pada kategori rendah dengan perilaku baik sebanyak 11 orang $(22,9 \%)$. Sosial Ekonomi pada kategori tinggi dengan perilaku kurang baik sebanyak 5 orang $(10,4 \%)$ dan sosial ekonomi pada kategori tinggi dengan perilaku baik sebanyak 18 orang $(37,5 \%)$. Dari hasil analisis statistik menggunakan uji Chi-Square diperoleh nilai probabilitas $(p$-value $)=0,033(p<\alpha=0,05)$. Maka hipotesis diterima, yang artinya ada hubungan sosial ekonomi dengan perilaku ibu dalam kehamilan di Rumah Sakit Umum Daerah Simeulue Tahun 2018.

Berdasarkan tabulasi silang antara kualitas pemeriksaan ANC dengan perilaku ibu dalam kehamilan, diketahui kualitas pemeriksaan ANC pada kategori tidak sesuai standar dengan perilaku kurang baik sebanyak 15 orang $(31,3 \%)$ dan kualitas pemeriksaan ANC pada kategori tidak sesuai standar dengan perilaku baik sebanyak 12 orang $(25,0 \%)$.
Kualitas pemeriksaan ANC pada kategori sesuai standar dengan perilaku kurang baik sebanyak 4 orang $(8,3 \%)$ dan kualitas pemeriksaan ANC pada kategori sesuai standar dengan perilaku baik sebanyak 17 orang $(35,4 \%)$.

Dari hasil analisis statistik menggunakan uji Chi-Square diperoleh nilai probabilitas $(p$-value $)=0,023(p<\alpha=$ $0,05)$. Maka hipotesis diterima, yang artinya ada hubungan kualitas pemeriksaan ANC dengan perilaku ibu dalam kehamilan di Rumah Sakit Umum Daerah Simeulue Tahun 2018.

Berdasarkan tabulasi silang antara pendidikan dengan perilaku ibu dalam kehamilan, diketahui bahwa pendidikan pada kategori rendah dengan perilaku kurang baik sebanyak 14 orang $(29,2 \%)$ dan pendidikan pada kategori rendah dengan perilaku baik sebanyak 9 orang $(18,8 \%)$. Pendidikan pada kategori tinggi dengan perilaku kurang baik sebanyak 5 orang $(10,4 \%)$ dan pendidikan pada kategori tinggi dengan perilaku baik sebanyak 20 orang $(41,6 \%)$.

Dari hasil analisis statistik menggunakan uji Chi-Square diperoleh nilai probabilitas $(p$-value $)=0,009(p<\alpha=$ 
0,05). Maka hipotesis diterima, yang artinya ada hubungan pendidikan dengan perilaku ibu hamil di Rumah Sakit Umum Daerah Simeulue Tahun 2018.

Berdasarkan tabulasi silang antara pengetahuan dengan perilaku ibu dalam kehamilan, diketahui bahwa pengetahuan pada kategori kurang baik dengan perilaku kurang baik sebanyak 16 orang (33,3\%) dan pengetahuan pada kategori kurang baik dengan perilaku baik sebanyak 10 orang (20,8\%). Pengetahuan pada kategori baik dengan perilaku kurang baik sebanyak 3 orang $(6,3 \%)$ dan pengetahuan pada kategori baik dengan perilaku baik sebanyak 19 orang (39,6\%).

Dari hasil analisis statistik menggunakan uji Chi-Square diperoleh nilai probabilitas $(p$-value $)=0,002(p<\alpha=$ $0,05)$. Maka hipotesis diterima, yang artinya ada hubungan pengetahuan dengan perilaku ibu dalam kehamilan di Rumah Sakit Umum Daerah Simeulue Tahun 2018.

Berdasarkan tabulasi silang antara dukungan keluarga dengan perilaku ibu dalam kehamilan, diketahui bahwa dukungan keluarga pada kategori tidak mendukung dengan perilaku kurang baik sebanyak 12 orang (25\%) dan dukungan keluarga pada kategori tidak mendukung dengan perilaku baik sebanyak 8 orang $(16,7 \%)$. Dukungan keluarga pada kategori mendukung dengan perilaku kurang baik sebanyak 7 orang (14,5\%) dan dukungan keluarga pada kategori mendukung dengan perilaku baik sebanyak 21 orang $(43,8 \%)$.

Dari hasil analisis statistik menggunakan uji Chi-Square diperoleh nilai probabilitas $(p$-value $)=0,032(p<\alpha=$ $0,05)$. Maka hipotesis diterima, yang artinya ada hubungan dukungan keluarga dengan perilaku ibu dalam kehamilan di Rumah Sakit Umum Daerah Simeulue Tahun 2018.

Berdasarkan tabulasi silang perilaku ibu dalam kehamilan dengan berat badan bayi lahir, diketahui bahwa perilaku pada kategori kurang baik dengan berat badan bayi pada kategori < 2500 gram sebanyak 11 orang $(22,9 \%)$ dan perilaku pada kategori kurang baik dengan berat badan bayi > 2500 gram sebanyak 8 orang $(16,7 \%)$. Perilaku pada kategori baik dengan berat badan bayi $\geq 2500$ gram sebanyak 2 orang $(4,1 \%)$ dan perilaku pada kategori baik dengan berat badan bayi $\geq 2500$ gram sebanyak 27 orang $(56,3 \%)$.

Dari hasil analisis statistik menggunakan uji Chi-Square diperoleh nilai probabilitas $(p$-value $)=0,000(p<\alpha=$ $0,05)$. Maka hipotesis diterima, yang artinya ada hubungan perilaku ibu dalam kehamilan dengan berat badan bayi lahir di Rumah Sakit Umum Daerah Simeulue Tahun 2018.

Tabel 2. Tabulasi silang antara Sosial Ekonomi, Kualitas Pemeriksaan ANC, Pendidikan, Pengetahuan, Dukungan Keluarga dengan perilaku ibu dalam kehamilan

\begin{tabular}{|c|c|c|c|c|c|c|c|c|}
\hline \multirow{3}{*}{ No } & \multirow{3}{*}{ Variabel } & \multicolumn{4}{|c|}{ Perilaku Ibu Hamil } & \multirow{2}{*}{\multicolumn{2}{|c|}{ Jumlah }} & \multirow{3}{*}{$p$-value } \\
\hline & & \multicolumn{2}{|c|}{ Kurang Baik } & \multicolumn{2}{|c|}{ Baik } & & & \\
\hline & & f & $\%$ & $f$ & $\%$ & $f$ & $\%$ & \\
\hline & Sosial Ekonomi & & & & & & & \\
\hline 1 & Rendah & 14 & 29,2 & 11 & 22,9 & 25 & 52,1 & \\
\hline 2 & Tinggi & 5 & 10,4 & 18 & 37,5 & 23 & 47,9 & 0,033 \\
\hline & Kualitas Pemeriksaan ANC & & & & & & & \\
\hline 1 & Tidak sesuai standar & 15 & 31,3 & 12 & 25,0 & 27 & 56,3 & ? ח ח \\
\hline 2 & Sesuai standar & 4 & 8,3 & 17 & 35,4 & 21 & 43,7 & 0,023 \\
\hline & Pendidikan & & & & & & & \\
\hline 1 & Rendah & 14 & 29,2 & 9 & 18,8 & 23 & 48 & \\
\hline 2 & Tinggi & 5 & 10,4 & 20 & 41,6 & 25 & 52 & ,009 \\
\hline & Pengetahuan & & & & & & & \\
\hline 1 & Kurang Baik & 16 & 33,3 & 10 & 20,8 & 26 & 54,1 & \\
\hline 2 & Baik & 3 & 6,3 & 19 & 39,6 & 22 & 45,9 & 0,002 \\
\hline & Dukung & & & & & & & \\
\hline 1 & Tidak Mendukung & 12 & 25 & 8 & 16,7 & 20 & 41,7 & 0,032 \\
\hline
\end{tabular}




\begin{tabular}{|c|c|c|c|c|c|c|c|c|}
\hline 2 & Mendukung & 7 & 14,5 & 21 & 43,8 & 28 & 58,3 & \\
\hline \multirow{3}{*}{ No } & \multirow{3}{*}{ Variabel } & \multicolumn{4}{|c|}{ Berat Badan Bayi } & \multirow{2}{*}{\multicolumn{2}{|c|}{ Jumlah }} & \multirow{3}{*}{$\begin{array}{c}P- \\
\text { Value }\end{array}$} \\
\hline & & \multicolumn{2}{|c|}{$<2500 \mathrm{gr}$} & \multicolumn{2}{|c|}{$\geq 2500 \mathrm{gr}$} & & & \\
\hline & & $f$ & $\%$ & $f$ & $\%$ & $f$ & $\%$ & \\
\hline & Perilaku Ibu hamil & & & & & & & \\
\hline 1 & Kurang Baik & 11 & 22,9 & 8 & 16,7 & 19 & 39,6 & 0,000 \\
\hline 2 & Baik & 2 & 4,1 & 27 & 56,3 & 29 & 60,4 & \\
\hline
\end{tabular}

Analisa Multivariat : Analisis multivariat yang digunakan dalam penelitian ini adalah regresi logistic binary yaitu untuk mengetahui faktor mana yang paling dominan mempengaruhi perilaku ibu dalam kehamilan di Rumah Sakit Umum Daerah Simeulue Tahun 2018.

uji regresi logistik (regresi berganda binary) melalui beberapa langkah antara lain:

1. Melakukan pemilihan variabel yang potensial dimasukkan dalam model variabel yang dipilih sebagai kandidat atau yang dianggap signifikan.

2. Dalam pemodelan ini variabel yang memiliki nilai $p$ value $<0,25$ pada uji bivariat (uji chi-square) dimasukkan secara bersama-sama dalam uji multivariat. Dari hasil uji bivariat, variabel yang dijadikan kandidat model pada uji logistic regression (regresi berganda binary) adalah variabel pengetahuan, sosial ekonomi, pengetahuan, kualitas pemeriksaan ANC, dan dukungan keluarga. Penggunaan kemaknaan statistik 0,25 dalam uji regresi statistik berganda untuk memungkinkan variabel-variabel yang secara terselubung sesungguhnya penting dimasukkan kedalam model multivariat. Variabel yang masuk seleksi kandidat model.

3. Selanjutnya dilakukan pengujian secara bersamaan dengan metode enter untuk mengidentifikasi variabel yang paling berpengaruh terhadap penggunaan kontrasepsi dengan signifikan $(p<0,05)$.

Dari seleksi variabel yang menjadi kandidat model dalam uji regresi logistik berdasarkan analisa bivariat menunjukkan bahwa ada 5 (lima) variabel yang $p$-value $<0,25$ yaitu pengetahuan, pendidikan, sosial ekonomi, kualitas pemeriksaan ANC dan dukungan keluarga. Dengan demikian ke 5 (lima) variabel tersebut layak masuk model multivariat.

\section{Tabel 4.18. Seleksi Variabel yang Menjadi Kandidat Model dalam Uji Regresi} Logistik Berdasarkan Analisa Bivariat

\begin{tabular}{clc}
\hline No & Variabel & p-value \\
\hline 1 & Pengetahuan & 0,002 \\
2 & Pendidikan & 0,009 \\
3 & Sosial Ekonomi & 0,033 \\
4 & Kualitas Pemeriksaan ANC & 0,023 \\
5 & Dukungan Keluarga & 0,032 \\
\hline
\end{tabular}

Setelah dilakukan uji regresi logistik tahap pertama menunjukkan bahwa dari 5 variabel bebas dari penelitian ini yang di uji secara logistik berganda pada tahap pertama, maka variabel yang $p_{\text {-value }}>0,05$ dikeluarkan dari analisis tahap kedua. Sedangkan $p$-value $<0,05$ maka akan masuk sebagai kandidat analisis tahap kedua dapat dilihat pada variabel yang memiliki nilai $p$ value yang paling tinggi dari 0,05 yaitu pendidikan 0,305 , dan selanjutnya variabel pendidikan dikeluarkan dari permodelan pada regresi logistik tahap kedua. 
Tabel 4.19. Seleksi Variabel Faktor Determinan Ibu Terhadap Berat Badan Bayi Lahir Di Rumah Sakit Umum Daerah (RSUD) Simeuleu Tahun 2018

\begin{tabular}{lcrr}
\hline \multicolumn{1}{c}{ Variabel } & B & Sig & \multicolumn{1}{c}{ Exp (B) } \\
\hline Seleksi 1 & & & \\
\hline Sosial Ekonomi & 1.655 & 0,092 & 5.235 \\
Kualitas Pemeriksaan ANC & 2.640 & 0,021 & 14.006 \\
Pendidikan & 1.108 & 0,305 & 3.028 \\
Pengetahuan & 2.775 & 0,019 & 16.034 \\
Dukungan Keluarga & 1.639 & 0,109 & 5.149 \\
\hline Constant & -3.832 & .002 & .022
\end{tabular}

Setelah dilakukan uji regresi logistik tahap kedua menunjukkan bahwa dari 4 variabel bebas dari penelitian ini yang di uji secara logistik berganda pada tahap pertama,maka variabel yang $p_{\text {-value }}>0,05$ dikeluarkan dari analisis tahap kedua. Sedangkan $p$-value $<0,05$ maka akan masuk sebagai kandidat analisis tahap ketiga dapat dilihat pada variabel yang memiliki nilai $p$ value yang paling tinggi dari 0,05 yaitu dukungan keluarga 0,151 , dan selanjutnya variabel dukungan keluarga dikeluarkan dari permodelan pada regresi logistik tahap kedua.

Hasil Uji Seleksi Tahap 2 Variabel Faktor Determinan Ibu Terhadap Berat Badan Bayi Lahir Di Rumah Sakit Umum Daerah (RSUD) Simeuleu Tahun 2018

\begin{tabular}{llcc}
\hline \multicolumn{1}{c}{ Variabel } & B & Sig & Exp(B) \\
\hline Seleksi 2 & & & \\
\hline Sosial Ekonomi & 1,684 & 0,077 & 5.388 \\
Kualitas Pemeriksaan ANC & 3,082 & 0,006 & 21.804 \\
Pengetahuan & 3,233 & 0,003 & 25.359 \\
Dukungan Keluarga & 1,332 & 0,151 & 3.788 \\
\hline Constant & -3.562 & .003 & .028 \\
\hline Dari hasil seleksi terakhir di peroleh & Tahun 2018 adalah pengetahuan, yang \\
variabel yang paling berpengaruh & mempunya nilai B paling besar yaitu 3,400 \\
dap perilaku ibu dalam kehamilan di & dan sig 0,002.
\end{tabular}
terhadap perilaku ibu dalam kehamilan di Rumah Sakit Umum Daerah Simeuleu

Hasil Uji Seleksi Tahap 3 Variabel Faktor Determinan Ibu Terhadap Berat Badan Bayi Lahir Di Rumah Sakit Umum Daerah (RSUD) Simeuleu Tahun 2018

\begin{tabular}{lccc}
\hline \multicolumn{1}{c}{ Variabel } & B & Sig & Exp (B) \\
\hline Seleksi 3 & & & \\
\hline Sosial Ekonomi & 1,936 & 0,035 & 6.930 \\
Kualitas Pemeriksaan ANC & 2,867 & 0,006 & 17.588 \\
Pengetahuan & 3,400 & 0,002 & 29.954 \\
\hline Constant & -2.906 & .004 & .055 \\
\hline
\end{tabular}


PEMBAHASAN

\section{Pengaruh Sosial Ekonomi Terhadap Perilaku Ibu Dalam Kehamilan Di Rumah Sakit Umum Daerah (RSUD) Simeulue Tahun 2018}

Hasil penelitian menunjukkan bahwa sosial ekonomi pada kategori rendah dengan perilaku kurang baik sebanyak 14 orang $(29,2 \%)$ dan sosial ekonomi pada kategori rendah dengan perilaku baik sebanyak 11 orang $(22,9 \%)$. Sosial ekonomi pada kategori tinggi dengan perilaku kurang baik sebanyak 5 orang $(10,4 \%)$ dan sosial ekonomi pada kategori tinggi dengan perilaku baik sebanyak 18 orang $(37,5 \%)$.

Hasil penelitian yang telah dilakukan dengan menggunakan uji Chi Square dapat diketahui bahwa ada hubungan sosial ekonomi dengan perilaku di Rumah Sakit Umum Daerah Simeulue Tahun 2018 dengan nilai $p$ value0,033 $(p<0,05)$. Sementara hasil uji logistic regression menunjukkan bahwa nilai sig 0,035 dengan nilai $B=1,936$, yang berarti pengaruh sosial ekonomi sebesar 1,936 kali terhadap perilaku ibu hamil.

Penelitian ini sejalan dengan hasil penelitian Penelitian yang dilakukan oleh Sagung Adi Sresti Mahayana, dengan judul "Faktor Risiko yang Berpengaruh terhadap Kejadian Berat Badan Lahir Rendah di RSUP Dr. M. Djamil Padang Pada 72 sampel yang didapatkan, faktor risiko janin dengan jenis kelamin laki-laki $(61,1 \%)$ dan status sosioekonomi rendah (52,8\%) memiliki proporsi yang lebih besar pada kejadian BBLR (22).

Menurut asumsi peneliti status sosial ekonomi merupakan kedudukan seseorang dalam lingkungannya baik itu pendidikan, pendapatan bahkan pekerjaannya. Faktor sosial ekonomi keluarga sering digambarkan dengan pendapatan keluarga. Pendapatan keluarga merupakan penggabungan pendapatan bersama ataupun perorangan yang didapatkan dari hasil kerja pokok dan diluar kerja pokok. Meningkatnya tingkat pendapatan keluarga akan menentukan kualitas dan kuantitas kebutuhan keluarga yang salah satunya adalah kemampuan untuk memenuhi kebutuhan ibu selama hamil, baik untuk gizi dan pemeriksaan ANC kefasilitas kesehatan. Hasil penelitian mayoritas menunjukkan status sosial ekonomi rendah sebanyak 25 keluarga $(52,1 \%)$ dengan perilaku ibu hamil kurang baik sebanyak 14 orang $(29,2 \%)$. Hal tersebut menunjukkan bahwa sosial ekonomi kerap kali menjadi salah satu alasan seseorang untuk bertindak. Biasanya orang yang memiliki sosial ekonomi yang tinggi akan bertindak sesuai dengan derajat sosial dan ekonominya.

Keluarga yang sosial ekonomi rendah akan berpikir ulang untuk melakukan pemeriksaan ANC karena untuk memeriksakan kehamilannya membutuhkan biaya, sehingga hal tersebut tidak menjadi yang prioritas untuk dilakukan. Ditambah lagi dengan rendahnya tingkat pengetahuan seseorang mengenai pentingnya melakukan pemeriksaan kehamilan, sehingga ibu tidak mengetahui anjuran dan pantangan makanan selama hamil. Sementara dari 25 keluarga (52,1\%) memiliki status ekonomi rendah, namun ada 11 orang $(22,9 \%)$ yang berperilaku baik selama hamil. Hal tersebut disebabkan karena adanya pengaruh tingkat pengetahuan ibu yang dia dapatkan baik dari pemeriksaan kehamilan ataupun dari media cetak dan elektronik sebagai salah satu alternative untuk menjaga kehamilannya sehingga anak yang dilahirkan dalam kondisi sehat yang dinilai dari berat badan saat lahir bahkan ibu berusaha untuk mencari tahu makanan apa yang baik untuk dikonsumsi saat hamil. Adanya pengaruh dukungan keluarga menambah perilaku ibu positif selama hamil untuk memeriksakan kehamilan sesuai dengan anjuran tenaga 
kesehatan serta pentingnya pengetahuan yang dimiliki ibu tentang pentingnya pemeriksaan kehamilan sehingga ibu berperilaku baik dalam menjaga kehamilannya agar terhindar dari berat badan bayi lahir rendah.

Status sosial ekonomi sangat berpengaruh terhadap kemampuan seseorang atau keluarga untuk memenuhi kebutuhannya terkait kehamilannya seperti pemeriksaan kehamilan, pemenuhan gizi dan kemampuannya untuk pergi ke fasilitas kesehatan. Hal ini dibuktikan dengan hasil peneltian menunjukkan bahwa status sosial ekonomi tinggi sebanyak 23 orang $(47,9 \%)$ dengan perilaku baik sebanyak 18 orang $(37,5 \%)$ yang dipengaruhi oleh keinginan ibu untuk mencari tahu tentang kehamilannya melalui keteraturan pemeriksaan kehamilan ada atau tidak ada kendala dalam menghadapi kehamilan saat ini terkait dengan pengetahuan ibu yang tinggi sseputar kehamilan, serta adanya dukungan keluarga yang maksimal selama ibu hamil seperti mengantarkan ibu untuk memeriksakan kehamilan, menanyakan hasil pemeriksaan kehamilan, dan lain sebagainya.

Namun status sosial ekonomi tinggi tidak menentukan perilaku baik yang dilihat dari status ekonomi tinggi sebanyak 23 orang (47,9\%) dengan perilaku buruk sebanyak 5 orang $(10,4 \%)$. Hal tersebut dipengaruhi oleh anggapan ibu bahwa kehamilan saat ini tidak ada kendala, sehingga ibu tidak melakukan pemeriksaan kehamilan karena pengalaman kehamilan sebelumnya yang tidak dilakukan pemeriksaan kehamilan, ibu mengikuti hormon kehamilannya yang malas makan, trauma akan mual dan muntah yang semuanya diakibatkan karena dukungan suami yang kurang memperhatikan atau menanyakan keluhan ibu selama hamil.

Pengaruh Kualitas Pemeriksaaan ANC Dengan Perilaku Ibu Dalam

\section{Kehamilan Di Rumah Sakit Umum Daerah (RSUD) Simeulue Tahun 2018}

Hasil penelitian menunjukkan bahwa kualitas pemeriksaan ANC pada kategori tidak sesuai standar dengan perilaku kurang baik sebanyak 15 orang $(31,3 \%)$ dan kualitas pemeriksaan ANC pada kategori tidak sesuai standar dengan perilaku baik sebanyak 12 orang (25,0\%). Kualitas pemeriksaan ANC pada kategori sesuai standar dengan perilaku kurang baik sebanyak 4 orang $(8,3 \%)$ dan kualitas pemeriksaan ANC pada kategori sesuai standar dengan perilaku baik sebanyak 17 orang $(35,4 \%)$.

Hasil penelitian yang telah dilakukan dengan menggunakan uji Chi Squarebahwa ada hubungan kualitas pemeriksaan ANC dengan perilaku di Rumah Sakit Umum Daerah Simeulue Tahun 2018 dengan nilai $p$-value 0,023 $(p<\alpha=0,05)$. Sementara hasil uji logistic regression menunjukkan bahwa nilai sig 0,006 dengan nilai $\mathrm{B}=2,867$, yang berarti pengaruh kualitas pemeriksaan ANC sebesar 2,867 kali terhadap perilaku ibu hamil.

Penelitian ini sejalan dengan Hidayatush (2015) tentang " Analisis Resiko Kejadian Bayi Berat Lahir Rendah (BBLR) pada Primigravida di Kabupaten Probolinggo" Menunjukkan bahwa Faktor yang mempengaruhi bayi berat lahir rendah (BBLR) adalah usia ibu, tingkat pendidikan, pendapatan keluarga, umur kehamilan, frekuensi dan kualitas antenatal serta tabu makanan.

Menurut asumsi peneliti kualitas pemeriksaan antenatal care sangat penting dalam upaya menurunkan angka kesakitan dan kematian ibu dan bayi. Pemeriksaan antenatal care (ANC) yang berkualitas dan memenuhi standar $10 \mathrm{~T}$ akan memberi manfaat dengan ditemukannya berbagai kelainan yang menyertai kehamilan secara dini, sehingga dapat diperhitungkan dan dipersiapkan langkah -langkah dalam pertolongan 
persalinannya. Kesehatan ibu yang optimal akan meningkatkan kesehatan, pertumbuhan dan perkembangan bayi. Keuntungan pemeriksaan ANC sangat besar karena dapat mengetahui berbagai risiko dan komplikasi kehamilan sehingga ibu hamil dapat diarahkan untuk tindakan selanjutnya. Jika ANC tidak dilakukan secara adekuat maka berbagai risiko dan komplikasi selama kehamilan tidak akan dapat di deteksi secara dini sehingga dapat mempengaruhi kesehatan ibu dan bayi. Hal ini tentu dapat menyebabkan bayi lahir dengan berat badan lahir rendah (BBLR).

Berdasarkan hasil penelitian yang di dapat menunjukkan bahwa mayoritas kualitas pemeriksaan ANC tidak sesuai standar sebanyak 27 orang (56,3\%) dengan perilaku kurang baik sebanyak 15 orang $(31,3 \%)$. Hal tersebut menunjukkan bahwa kualitas pemeriksaan ANC dapat memantau dan menginformasikan ibu hamil mengenai kondisi kehamilannya selama hamil, sehingga dapat mencegah terjadinya kondisi berat badan lahir yang rendah. Hasil jawaban responden menunjukkan bahwa pada kualitas pemeriksaan ANC mayoritas menjawab tidak pada pertanyaan seputar pengukuran lingkar lengan atas ibu selama ibu melakukan pemeriksaan ANC, padahal pengukuran tersebut dapat memantau status gizi ibu hamil yang berimplikasi terhadap kondisi janinnya yang disebabkan tenaga kesehatan merasa dengan mengukur TB dan BB, maka standar pelayanan ANC yaitu mengukur lingkar lengan atas tidak perlu lagi. Pada pertanyaan seputar pemeriksaan HB ibu menyatakan tidak diperiksa $\mathrm{HB}$ nya. Kedua hal tersebut terkait dengan ibu hamil hanya memeriksakan kehamilannya tidak sesuai dengan frekuensi kunjungan, sehingga ibu tidak mendapatkan pemeriksaan HB yang seharusnya ibu dapatkan. Pentingnya kualitas pemeriksaan ANC terkait dengan pengetahuan ibu tentang pentingya kualitas pemeriksaan ANC sesuai dengan jadwal kunjungan, sehingga ibu mendapatkan standar pelayanan ANC yang optimal dari tenaga kesehatan.

Sementara dari kualitas pemeriksaan ANC tidak sesuai standar sebanyak 27 orang $(56,3 \%)$ dengan perilaku baik sebanyak 12 orang (25,0\%). Hal tersebut dipengaruhi oleh adanya faktor pendorong lainnya seperti pengetahuan ibu tentang informasi atau tanda-tanda kehamilan yang sehat melalui berbagai media cetak, eloktronik dan pengalamannya selama hamil dan juga di pengaruhi oleh faktor pendorong lainnya seperti pendidikan ibu hamil dan keluarga, pengetahuan, sosial ekonomi keluarga ibu hamil dan dukungan dari keluarga.

Pemerikaan kehamilan yang ibu lakukan sesuai dengan standar pemeriksaan kehamilan yang dianjurkan oleh tenaga kesehatan akan membantu ibu untuk mendapatkan standar pemeriksaan kehamilan pada saat ibu melakukan pemeriksaan kehamilan yang sudah dijadwalkan oleh tenaga kesehatan. Hal tersebut dapat dilihat dari kualitas pemeriksaan ANC sesuai standar sebanyak 21 orang $(43,8 \%)$ dengan perilaku baik sebanyak 17 orang $(35,4 \%)$ yang dipengaruhi oleh pengetahuan ibu yang baik dalam melakukan pemeriksaan kehamilan sesuai dengan jadwalnya, sehingga ibu mendapatkan semua standar pemeriksaan kehamilan sesuai dengan tahap dan hasil pemeriksaan kehamilan dan ibu dan suami mau melaksanakan apa yang menjadi hasil konseling yang harus dilakukan atau dijauhi selama hamil. Sementara dari 21 orang $(43,8 \%)$ ada ibu dengan perilaku kurang baik sebanyak 4 orang $(8,3 \%)$. Hal tersebut dipengaruhi oleh pengetahuannya yang kurang baik dalam melakukan pemeriksaan kehamilan, sehingga ibu merasa pemeriksaan tersebut tidak penting 
untuk dilakukan dan pengetahuan ibu yang baik sekalipun mengenai pemeriksaan ANC namun tidak mau melakukan pemeriksaan kehamilan, akibat kendala status sosial ekonomi dan kurangnya dukungan dari suami untuk melakukan pemeriksaan kehamilan.

\section{Pengaruh Pendidikan Terhadap Perilaku Ibu Dalam Kehamilan Di Rumah Sakit Umum Daerah (RSUD) Simeulue Tahun 2018}

Hasil penelitian menunjukkan bahwa pendidikan pada kategori rendah dengan perilaku kurang sebanyak 14 orang $(29,2 \%)$ dan pendidikan pada kategori rendah dengan perilaku baik sebanyak 9 orang $(18,8 \%)$. Pendidikan pada kategori tinggi dengan perilaku kurang baik sebanyak 5 orang $(10,4 \%)$ dan pendidikan pada kategori tinggi dengan perilaku baik sebanyak 20 orang $(41,6 \%)$.

Hasil penelitian yang telah dilakukan dengan menggunakan uji Chi Square bahwa ada hubungan pendidikan dengan perilaku di Rumah Sakit Umum Daerah Simeulue Tahun 2018 dengan nilai $p$-value 0,009 $(p<\alpha$ $=0,05)$. Sementara hasil uji logistic regression menunjukkan bahwa nilai Sig 0,305 dengan nilai $B=1,108$, yang berarti tidak ada pengaruh pendidikan sebesar 1,108 kali terhadap perilaku ibu hamil.

Penelitian ini tidak sejalan dengan hasil penelitian yang dilakukan oleh Hidayatush (2015) tentang " Analisis Resiko Kejadian Bayi Berat Lahir Rendah (BBLR) pada Primigravida di Kabupaten Probolinggo" Menunjukkan bahwa faktor yang mempengaruhi bayi berat lahir rendah (BBLR) adalah usia ibu, tingkat pendidikan, pendapatan keluarga, umur kehamilan, frekuensi dan kualitas antenatal serta tabu makanan. Tingkat pendidikan memiliki nilai $p$-value sebesar 0,023 (18).
Menurut asumsi peneliti pendidikan merupakan salah satu penunjang pola pikir seseorang dalam menerima informasi atau tingkat pengetahuan seseorang untuk menganalisis setiap informasi yang akan ibu ikuti atau tidak ikuti dalam melakukan perubahan pada perilakunya yang biasanya didukung oleh lingkungannya. Pendidikan turut berperan dalam kejadian berat badan bayi lahir rendah, karena umunya seseorang yang memiliki pendidikan yang tinggi akan lebih mudah mengerti berbagai informasi terkait berat badan lahir bayi, pendidikan yang tinggi lebih memungkinkan seseorang itu menerima dan mencari informasi yang berkaitan dengan keadaan yang di alaminya. Dengan pendidikan yang tinggi diharapkan seseorang itu lebih terbuka mengenai berbagai hal dan juga lebih selektif untuk menentukan hal yang lebih berguna dan bermanfaat untuk keadaan yang dialaminya. Pendidikan akan mengajarkan seseorang tata cara untuk berperilaku, perilaku seseorang menunjukkan tingkat pendidikan yang di milikinya. Seseorang yang memiliki tingkat pendidikan yang baik atau tinggi akan berperilaku sesuai dengan pendidikannya dan sesuai dengan apa yang diketahuinya.

Hasil penelitian menunjukkan bahwa mayoritas pendidikan ibu tinggi sebanyak 25 orang $(52,1 \%)$ dengan perilaku baik sebanyak 20 orang $(41,7 \%)$. Hal tersebut menunjukkan bahwa tingkat pendidikan menentukan mudah tidaknya seseorang menyerap dan memahami pengetahuan gizi yang mereka peroleh. Pendidikan orang tua merupakan salah satu faktor penting dalam tumbuh kembang anak. Karena dengan pendidikan yang baik, maka orang tau dapat menerima segala informasi dari luar terutama cara pengasuhan anak yang baik, bagaimana menjaga kesehatan 
anaknya, pendidikannya dan sebagainya.

Pendidikan berpengaruh pada faktor sosial ekonomi lainnya seperti pendapatan, pekerjaan, kebiasaan hidup, makanan, perumahan dan tempat tinggal. Sehingga sesuai dengan hasil penelitian yang telah di dapat bahwa tingkat pendidikan ibu hamil akan mempengaruhi perilaku ibu hamil. Pendidikan diperlukan untuk memperoleh informasi, dalam hal ini adalah informasi kesehatan.Seorang ibu yang memiliki pendidikan tinggi akan lebih terbuka pemahamannya dan penerimaannya terhadap informasi yang ada. Pendidikan juga kerap kali dikaitkan dengan keinginan untuk mencari berbagai sumber yang hendak atau ingin diketahuinya apalagi yang berkaitan dengan dirinya sendiri. Sehingga ibu dengan pendidikan tinggi lebih berpotensi untuk berperilaku mencegah terjadinya berat badan lahir rendah pada bayi yang dikandungnya.

Sementara mayoritas pendidikan ibu tinggi sebanyak 25 orang $(52,1 \%)$ dengan perilaku kurang baik sebanyak 5 orang (10,4\%). Hal tersebut erat kaitannya dengan adanya faktor lingkungan sekitar ibu berdomisili, yaitu pengaruh suami dan keluarga terhadap perilaku ibu selama hamil. Pengaruh tersebut bisa positif dan negatif tergantung dari nilai kepercayaan yang suami atau keluarga anut, seperti suami kurang mendukung ibu selama hamil baik dengan perbuatan atau perkataan. Misalnya suami tahu istrinya hamil namun tetap merokok disekitarnya ataupun suami tidak mendukung ibu untuk periksa kehamilan terkait dengan pengalaman ibu hamil sebelumnya. Rendahnya pendapatan juga dapat mempengaruhi ibu untuk melakukan pemeriksaan kehamilan dan memenuhi kebutuhan makanan secara kualitas yang baik selama hamil, sebab ibu akan memikirkan kembali pentingnya pemeriksaan kehamilan untuk dilakukan jika pendapatan tidak mencukupi bahkan untuk membeli makanan yang baik, sehingga berpengaruh terhadap kesehatan ibu dan janinnya.

Pendidikan merupakan suatu proses membelajarkan individu sehingga berpengaruh terhadap pola pikirnya dalam melakukan tindakan yang dia anggap baik atau tidak baik. Hal tersebut dapat dilihat dari 23 orang $(47,9 \%)$ yang berpendidikan rendah dengan 14 orang $(29,2 \%)$ berperilaku kurang baik. Masalah tersebut dipengaruhi oleh proses ibu dalam memproses informasi tersebut kurang optimal, seperti ibu harus menjauhi paparan asap rokok, namun karena ibu merasa bahwa tidak merokok secara langsung membuat ibu tidak menjauhi asap rokok. Hal tersebut berhubungan dengan pola pikirnya dalam memproses setiap informasi yang ia terima. Sementara dari 23 orang $(47,9 \%)$ yang berpendidikan rendah ada 9 orang $(18,8 \%)$ yang berperilaku baik. Hal tersebut dipengaruhi oleh pengaruh dari orang sekitarnya atau suami yang mendukung ibu untuk melakukan pemeriksaan kehamilan, sehingga ibu dan suami dapat memperoleh informasi yang baik seputar kehamilannya.

Berdasarkan uji logistic regression didapatkan bahwa tidak ada pengaruh antara pendidikan dengan perilaku ibu hamil yang disebabkan karena pada dasarnya pendidikan merupakan faktor pembentuk dari perilaku ibu hamil terkait dengan pengetahuannya. Pendidikan tinggi tidak menjamin perilaku ibu hamil dalam berperilaku baik dan begitu juga sebaliknya. Pendidikan adalah proses pembelajaran seseorang untuk mengubah perilakunya kearah yang lebih baik, namun ada beberapa faktor yang mempengaruhi perubahan perilaku tersebut seperti pengetahuan dari kepercayaan/orang sekitarnya, sosial ekonomi dan pengalamannya 
yang mempengaruhi perilaku ibu selama hamil.

\section{Pengaruh Pengetahuan Dengan Perilaku Ibu Dalam Kehamilan Di Rumah Sakit Umum Daerah (RSUD) Simeulue Tahun 2018}

Hasil penelitian menunjukkan bahwa pengetahuan pada kategori kurang dengan perilaku kurang baik sebanyak 16 orang $(33,3 \%)$ dan pengetahuan pada kategori kurang dengan perilaku baik sebanyak 10 orang (20,8\%). Pengetahuan pada kategori baik dengan perilaku kurang sebanyak 3 orang $(6,3 \%)$ dan pengetahuan pada kategori baik dengan perilaku baik sebanyak 19 orang $(39,6 \%)$.

Hasil penelitian yang telah dilakukan dengan menggunakan uji Chi Square bahwa ada hubungan pengetahuan dengan perilaku di Rumah Sakit Umum Daerah Simeulue Tahun 2018 dengan nilai $p$-value 0,002 $(p<\alpha=0,05)$. Sementara hasil uji logistic regression menunjukkan bahwa nilai sig 0,002 dengan nilai $\mathrm{B}=3,400$, yang berarti ada pengaruh pengetahuan sebesar 3,400 kali terhadap perilaku ibu hamil.

Menurut asumsi peneliti pengetahuan adalah hasil dari tahu/mengetahui yang terjadi setelah orang melakukan pengindraan, seperti mendengar informasi terhadap suatu objek tertentu yang berperan penting dalam pembentukan perilaku seseorang terkait dengan informasi yang telah ia dapatkan. Ada 6 tingkatan yang mempengaruhi pengetahuan ibu hamil yang pertama adalah tahu atau know terkait dengan ibu meningat bahwa pemeriksaan kehamilan penting untuk dilakukan, yang kedua adalah memahami atau comprehention terkait dengan ibu sudah mampu untuk menjelaskan pentingnya pemeriksaan kehamilan untuk dilakukan dan bisa mengajak orang untuk memahami pemeriksaan tersebut, yang ketiga adalah aplikasi atau aplication terkait dengan ibu sudah mulai menerapkan informasi pemeriksaan kehamilan untuk dirinya, yang keempat adalah analisis atau analysis terkait dengan kemampuan ibu untuk membedakan baik atau buruknya sebuah informasi yang ibu dapatkan, yang kelima adalah sintesis atau syntesis terkait dengan kemampuan ibu untuk menyesuaikan informasi tersebut kekondisi dirinya, dan yang keenam adalah evaluasi atau evaluation terkait dengan kemampuan ibu untuk menilai suatu informasi pemeriksaan kehamilan bila ada pertanyaan yang diajukan ibu bisa menjawabnya. Hasil penelitian menunjukkan bahwa mayoritas pengetahuan ibu kurang baik sebanyak 26 orang $(54,2 \%)$ dengan perilaku kurang baik sebanyak 16 orang $(33,3 \%)$. Hal tersebut disebabkan karena berdasarkan tingkat dari pengetahuan masih berada pada tingkat yang pertama yaitu mengetahui pentingnya pemeriksaan ANC dalam mendeteksi kondisi janin agar terhindar dari bahaya yang salah satunya adalah berat bayi lahir rendah. Pada dasarnya pendidikan hanya sebagai proses atau kemampuan seseorang untuk menalari suatu informasi yang ia dapatkan melalui pancaindera. Setiap informasi yang ia terima tergantung dari siapa yang memberikan informasi tersebut dan bagiamana si pemberi informasi mampu untuk mempengaruhi pengetahun ibu sehingga terjadi perubahan perilaku. Adanya pengalaman sebelumnya ibu hamil akan mempengaruhi pengetahuan ibu dalam menjaga kehamilannya, sehingga ibu merasa tidak perlu untuk melakukan pemeriksaan kehamilan terkait dengan kondisi bayi yang sebelumnya ibu lahirkan.

Sementara dari 26 orang $(54,2 \%)$ yang memiliki pengetahuan kurang dengan perilaku baik sebanyak 10 orang (20,8\%). Hal tersebut dipengaruhi oleh adanya dukungan 
keluarga untuk melakukan pemeriksaan kehamilan, baik dari segi keuangan, mengantarkan ibu melakukan pemeriksaan kehamilan sehingga dapat dipantau bagaimana kondisi kehamilan ibu pada saat ini dan ibu mau mengikuti anjuran dan pantangan selama hamil oleh bidan serta memenuhi kebutuhan makanan yang sesuai kebutuhan ibu selama hamil.

Seseorang yang memiliki pengetahuan akan bertindak sesuai dengan yang diketahuinya, seorang ibu hamil yang mengetahui apa penyebab dan akibat dari berat badan bayi lahir rendah akan berusaha agar bayinya terhindar dari berat badan bayi lahir rendah. Dengan alasan bahwa seorang ibu hamil mengetahui penyebab berat badan lahir rendah maka ibu hamil tersebut akan melakukan hal yang dapat mencegahnya seperti mengkonsumsi makanan yang bergizi dan bervariasi serta memeriksakan kehamilannya sehingga ibu hamil itu mengetahui apa yang selanjutkan akan dilakukan dengan kehamilannya. Hasil penelitian menunjukkan dari 25 orang $(45,8 \%)$ berpengatahuan baik dengan perilaku baik sebanyak 19 orang $(39,6 \%)$ yang dipengaruhi oleh adanya dasar ibu untuk melakukan apa yang baik dan tidak selama ibu hamil. Dengan melakukan semua yang ibu ketahui seperti melakukan pemeriksaan kehamilan, menjaga pola makan dan sebagainya, maka diharapkan janin yang dikandungnya terhindar dari berat badan lahir rendah. Namun dari 25 orang ibu yang berpengetahuan baik 3 orang $(6,3 \%)$ ternyata berperilaku kurang baik. Hal tersebut dipengaruhi tingkat sosial ekonomi yang rendah menyebabkan ibu tidak mampu memenuhi kebutuhan gizi dan kesehatan, adanya dukungan keluarga yang kurang baik terkait dengan kehamilan yang ibu alami sekarang ini. $\begin{array}{llr}\text { Pengaruh } & \text { Dukungan Keluarga } \\ \text { Dengan Perilaku Ibu } & \text { Dalam } \\ \text { Kehamilan Di Rumah Sakit Umum } \\ \text { Daerah (RSUD) Simeulue Tahun } 2018\end{array}$

Hasil penelitian menunjukkan bahwadukungan keluarga pada kategori tidak mendukung dengan perilaku kurang baik sebanyak 12 orang (25\%) dan dukungan keluarga pada kategori tidak mendukung dengan perilaku baik sebanyak 8 orang $(16,7 \%)$. Dukungan keluarga pada kategori mendukung dengan perilaku kurang baik sebanyak 7 orang (14,5\%) dan dukungan keluarga pada kategori mendukung dengan perilaku baik sebanyak 21 orang $(43,8 \%)$.

Hasil penelitian yang telah dilakukan dengan menggunakan uji Chi Square bahwa ada hubungan dukungan keluarga dengan perilaku di Rumah Sakit Umum Daerah Simeulue Tahun 2018 dengan nilai $p$-value 0,032 ( $p<\alpha=0,05)$. Sementara hasil uji logistic regression menunjukkan bahwa nilai sig 0,151 dengan nilai $B=1,332$, yang berarti tidak adan pengaruh dukungan keluarga sebesar 1,332 kali terhadap perilaku ibu hamil.

Menurut asumsi peneliti perilaku dapat dipengaruhi beberapa faktor yaitu pengetahuan ibu dalam menjaga kehamilannya baik dengan melakukan pemeriksaan kehamilan atau menjaga pola makan, aktivitas dan istirahat, faktor dukungan keluarga dalam menjaga dan mengawasi ibu terkait dengan peran keluarga yang sangat penting untuk ibu hamil dalam berperilaku untuk menjaga kehamilannya. Hasil penelitian menunjukkan bahwa mayoritas suami atau keluarga mendukung sebanyak 28 orang $(58,3 \%)$ dengan perilaku ibu hamil baik sebanyak 21 orang $(43,8 \%)$. $\mathrm{Hal}$ tersebut menunjukkan bahwa anggota keluarga merasa bahwa seorang ibu hamil sangat rentan terkena stress sehingga membutuhkan pertolongan dan bantuan untuk memantau, mengingatkan ibu 
mengenai apa yang baik dan tidak baik dilakukan selama hamil. Dukungan keluarga terutama suami sangat dominan dalam mengurangi kecemasan selama kehamilan. Tempat inilah ibu menyampaikan keluh kesah yang dirasakan selama hamil, keluh kesah ini jika ditanggapi dengan positif, memberikan dukungan moral, motivasi sehingga beban moral yang dirasakan akan berkurang karena peranan suami, sehingga ibu merasa nyaman selama hamil dan mau melakukan apa yang baik untuk kehamilannya.

Bukti dukungan yang diberikan bukan hanya sebatas mengantarkan atau memenuhi kebutuhan ibu selama hamil, namun suami atau keluarga juga menjaga diri dari hal-hal yang membuat ibu mengalami masalah terutama masalah berat badan lahir bayi, seperti merokok. Adanya pengetahuan ibu yang baik mengenai masalah kehamilan dan bahaya yang dihindari sehingga anak lahir sehat akan terlaksana bila suami pun mau melakukan larangan yang ibu maksudkan, seperti makanan yang baik untuk kandungannya dan suami mau memenuhi kebutuhan tersebut bahkan istri melarang suami merokok, maka suami harus mau berhenti atau tidak berada disekitar istri untuk merokok.

Sementara dari keluarga yang mendukung sebanyak 28 orang $(58,3 \%)$ dengan perilaku kurang baik sebanyak 7 orang (14,6\%). Hal tersebut bisa juga dipengaruhi oleh tingkat pengetahuan ibu selama hamil yang dipengaruhi oleh pengalaman ibu hamil sebelumnya yang tidak ada kendala selama hamil dan bayi lahir dengan sehat, sehingga pengalaman tersebut dijadikan acuan untuk berperilaku hamil berikutnya.

Dukungan berperan penting dalam menyikapi kehamilan seorang ibu terkait dengan bagaimana suami atau keluarga memberikan bantuan, perhatian dan kasih sayang, sehingga mempengaruhi kesehatan ibu secara fisik, psikologis dan sosial ibu. Hal tersebut dapat dilihat dari 20 orang $(41,7 \%)$ ibu yang tidak mendapat dukungan dari keluarga dengan 12 orang $(20,5 \%)$ ibu berperilaku kurang baik selama hamil. Masalah tersebut dipengaruhi oleh pentingnya dukungan keluarga dalam memberikan kenyamanan ibu selama hamil, ditambah lagi kurangnya pengetahuan ibu terkait seputar kehamilan, sehingga ibu jadi malas melakukan pemeriksaan kehamilan dan tidak melakukan anjuran tenaga kesehatan terkait hasil pemeriksaan kehamilannya. Rendahnya dukungan keluarga juga dipengaruhi oleh status sosial ekonomi yang rendah serta ketidakpedulian keluarga terhadap kehamilan istrinya terkait dengan budaya patriaki yang melekat didiri keluarga atau suami. Sementara dari 20 orang $(41,7 \%)$ ibu yang tidak mendapat dukungan keluarga didapatkan 8 orang $(16,7 \%)$ ibu yang berperilaku baik, terkait dengan kemampuan ibu baik secara materi dan pengetahuan yang baik serta kepedulian ibu terhadap kesehatan dirinya sendiri untuk melaksanakan apa yang baik yang dianjurkan oleh tenaga kesehatan bahkan informasi baik dari media cetak maupun elektronik mengenai kehamilan yang sehat.

Berdasarkan uji logistic regression didapatkan bahwa tidak ada pengaruh antara dukungan keluarga dengan perilaku ibu hamil yang disebabkan karena adanya pengaruh dari pengalaman ibu tentang kehamilan sebelumnya tentang pentingnya pemeriksaan kehamilan dan ibu konsisten untuk mencari informasi seputar kehamilannya baik dari media elektronik dan non elektronik, sehingga ibu mengetahui bagaimana menjaga kehamilannya tetap sehat dan janinnya terhindar dari berat badan lahir rendah.

Hubungan Perilaku Ibu Dalam
Kehamilan Dengan Berat Badan Bayi 


\section{Lahir Di Rumah Sakit Umum Daerah (RSUD) Simeulue Tahun 2018}

Hasil penelitian menunjukkan bahwa perilaku pada kategori kurang dengan berat badan bayi < 2500 gram sebanyak 11 orang $(22,9 \%)$ dan perilaku pada kategori kurang dengan berat badan bayi $\geq 2500$ gram sebanyak 8 orang $(16,7 \%)$. Perilaku pada kategori baik dengan berat badan bayi $<2500$ gram sebanyak 2 orang $(4,1 \%)$ dan perilaku pada kategori baik dengan berat badan bayi $\geq 2500$ gram sebanyak 27 orang $(56,3 \%)$.

Hasil penelitian yang telah dilakukan dengan menggunakan uji Chi Square bahwa ada perilaku dengan berat badan lahir rendah di Rumah Sakit Umum Daerah Simeulue Tahun 2018 dengan nilai $p$-value $0,000(p<\alpha$ $=0,05)$. Maka hipotesis diterima, yang artinya ada hubungan perilaku dengan berat badan bayi lahir di Rumah Sakit Umum Daerah Simeulue Tahun 2018.

Menurut asumsi peneliti perilaku adalah suatu kegiatan atau aktivitas organisme (mahluk hidup) yang bersangkutan, baik yang dapat diamati maupun yang tidak dapat diamati oleh pihak luar. Perilaku pada dasarnya adalah suatu respons seseorang terhadap stimulus. Respons tersebut bersifat aktif, yaitu berupakan tindakan yang nyata. Pembentukan atau perubahan perilaku dipengaruhi oleh beberapa faktor yang berasal dari dalam dan dari luar individu itu sendiri. Faktor intern mencakup pengetahuan , sikap, kecerdasan, persepsi, emosi, dan motivasi. Adapun faktor ekstern meliputi lingkungan sekitar, sosial ekonomi dan kebudayaan. Hasil penelitian menunjukkan bahwa perilaku ibu selama hamil dapat mempengaruhi kondisi bayi lahir dengan berat badan lahir rendah. Dari 19 ibu yang berperilaku kurang baik ditemukan 11 bayi lahir dengan berat badan lahir rendah $(22,9 \%)$ dan 8 bayi lahir dengan berat badan normal (16,7\%). Berdasarkan penelitian ini perilaku ibu selama kehamilan berpengaruh terhadap berat badan bayi lahir. Perilaku yang baik selama kehamilan akan menghasilkan yang baik juga. Ibu yang berperilaku untuk menjaga kehamilan dengan mengkonsumsi makanan yang bergizi dan bervariasi serta memeriksakan kehamilannya akan lebih memungkinkan untuk melahirkan bayi dengan berat badan bayi normal. Hasil penelitain menunjukkan bahwa selama hamil ibu yang memilki anak dengan berat badan lahir rendah terpapar dengan asap rokok, baik dari suami sendiri atau orang lain dilingkungan rumah tersebut. Hal tersebut tidak bisa dicegah oleh ibu sebab sudah menjadi kebiasaan oleh suaminya untuk merokok dan perilaku tersebut tidak bisa dihindari oleh si ibu. Rendahnya dukungan keluarga terkait dengan masalah ekonomi membuat ibu tidak bisa memeriksakan kehamilannya kefasilitas kesehatan bahkan adanya kepercayaan ibu selama hamil untuk bekerja keras selama hamil dapat membuat ibu bersalin dengan normal.

Sementara dari 19 ibu yang berperilaku kurang baik ditemukan 8 bayi lahir dengan berat badan normal $(16,7 \%)$. Hal tersebut erat kaitannya dengan pengetahuan ibu selama hamil yang mempengaruhi tindakannya, yaitu menjaga pola makan walaupun ibu terpapar asap rokok, namun sebisa mungkin ibu menghindari paparan tersebut. Perilaku yang baik dalam pencegahan berat bayi lahir rendah akan menghasilkan bayi yang dilahirkan dengan keadaan berat badan normal karena ibu hamil yang berperilaku baik dalam mencegah berat badan lahir rendah pada bayinya akan mengupayakan berbagai tindakan agar bayi yang hendak dilahirkannya memiliki berat badan yang normal.

Perilaku yang baik selama hamil akan mempengaruhi kesehatan janin yang dikandungnya. Hal tersebut dapat dilihat dari 29 orang $(60,4 \%)$ perilaku ibu baik dengan melahirkan bayi normal 
sebanyak 27 orang (56,3\%). Data tersebut menunjukkan bahwa semakin baik perilaku ibu dalam menjaga kehamilannya maka anak yang dilahirkannya akan sehat dan terhindar dari masalah berat badan lahir rendah. Sementara dari 29 orang $(60,4 \%)$ yang berperilaku baik namun ada 2 orang $(4,2 \%)$ yang melahirkan bayi dengan berat badan lahir rendah. Hal tersebut menunjukkan bahwa perilaku ibu baik, terkait dengan kognitip, apektif dan psikomotorik dalam menjaga kehamilannya namun jika orang-orang sekitarnya tidak peduli dalam menjaga kehamilan si istri, maka berat badan anak bisa lahir rendah. Ibu hamil sangat resisten terhadap tekanan dan sensitif terhadap perilaku orang sekitarnya, sehingga adanya anggapan ibu yang merasa ia kurang diperhatikan menyebabkan ibu tidak mau makan, karena takut mual, malas memeriksan kehamilan, sehingga bisa saja terjadi berat badan lahir rendah.

\section{Faktor Dominan Yang Mempengaruhi Perilaku Ibu Dalam Kehamilan Di Rumah Sakit Umum Daerah (RSUD) Simeulue Tahun 2018}

Hasil penelitian yang telah dilakukan dapat diketahui bahwa ada faktor yang paling dominan mempengaruhi perilaku ibu hamil di Rumah Sakit Umum Daerah adalah faktor pengetahuan dengan nilai sig $p$ value $0,002(p<0,05)$ B sebesar 3,400 . Artinya pengetahuan memiliki pengaruh terhadap perilaku ibu hamil sebesar 3,400 kali dibandingkan variabel lainnya dengan nilai $p$-value sebesar $0,002<0,005$.

Hasil penelitian ini sejalan dengan oleh Komaria (2008), dengan judul"Hubungan Pengetahuan, Sikap dan Perilaku Ibu Hamil tentang Pemeriksaan Kehamilan dengan Kunjungan Pemeriksaan Kehamilan di Wilayah Kerja Puskesmas Sukarame
Mojoroto Kediri". Penelitian ini bersifat metode deskriptif korelatif dengna pendekatan cross sectional. Teknik sampling yang digunakan adalah purposive sampling sebanyak 45 responden trimester III. Hasil penelitian menunjukkan bahwa ada hubungan positif dan signifikan antara pengetahuan dan kunjungan pemeriksaan ibu hamil (nilai $r=0,554$ ), hasil uji statistik diperoleh nilai $p_{\text {value }}$ sebesar 0,000 dan nilai $p$ untuk uji t sebesar 0,000.

Perilaku kesehatan adalah suatu respons seseorang (organisme) terhadap stimulus atau objek yang berhubungan dengan sakit dan penyakit, system pelayanan kesehatan, makanan dan minuman serta lingkungan.

Menurut asumsi peneliti perilaku erat kaitannya dengan pengetahuan individu untuk memproses informasi untuk bersikap dalam menerima informasi tersebut sehingga adanya sebuah tindakan untuk melakukan aktivitas yang berhubungan dengan kesehatannya dan bukan berarti pengetahuan tinggi akan menunjukkan perilaku baik dan sebaliknya pengetahuan rendah akan menunjukkan perilaku yang rendah. Ada beberapa faktor yang mempengaruhi tingkat pengetahuan ibu yaitu pendidikan berpengaruh terhadap pola pikir, pekerjaan berpengaruh terhadap aktivitas sosial si ibu, pengalaman yang ibu dapatkan sebelumnya, kepercayaan, dukungan orang sekitarnya dan dorongan untuk mencari informasi dari sumber yang ibu percaya.

Faktor-faktor diatas akan
mempengaruhi pengetahuan ibu
melalui dua aspek yang berbeda yaitu
aspek positif dan aspek negatif yang
akan mempengaruhi sikap ibu terhadap
objek tersebut, seperti ibu menerima
bahwa pemeriksaan kehamilan
kepetugas kesehatan baik untuk


memantau kondisi janin dan sekaligus mendapatkan informasi yang benar dari petugas kesehatan itu sendiri. Ditambah lagi dengan adanya pendidikan yang tinggi yang akan mempermudah proses penerimaan informasi tersebut yang disebut dengan perilaku tertutup (convert behaviour), seperti ibu tahu bahwa kunjungan antenatal care itu penting untuk kesehatan ibu dan janin, dan mau memeriksakan kehamilannya ke petugas kesehatan (pengetahuan positif mempenagruhi sikap positif) atau masih saja malas untuk pergi berkunjung/memeriksakan

kehamilannya (pengetahuan positif mempengaruhi sikap negatif) atau sebaliknya.

Apabila ibu berperilaku terbuka maka ibu akan menunjukkannya dengan tindakan nyata yang mudah diamati atau dinilai oleh orang lain. Seperti ibu patuh untuk memeriksakan ANC dan melakukan anjuran tenaga kesehatan sesuai dengan hasil pemeriksaan kehamilannya ataupun sebaliknya.

Adanya pengetahuan mengenai kehamilan yang baik akan mempengaruhi perilaku ibu hamil dalam mengatasi dan mencegah anaknya lahir dengan kondisi berat badan lahir rendah. Pengetahuan ibu yang baik akan mempengaruhi ibu untuk mencari tahu bagaiamana agar kondisi kehamilannya sehat (perilaku terbuka) baik dengan melakukan pemeriksaan kehamilan yang teratur atau mengkonsumsi makanan yang bergizi dan sehat atau bahkan menghindari paparan asap yang berpengaruh terhadap kondisi janinnya.

\section{KESIMPULAN}

Dari hasil penelitian yang telah di lakukan di Rumah Sakit Umum Daerah (RSUD) Simeuleu dengan responden sebanyak 48 orang, maka peneliti dapat menarik kesimpulan yaitu:
1. Ada pengaruh pengetahuan dengan perilaku ibu hamil di Rumah Sakit Umum Daerah Simeulue Tahun 2018 dengan nilai $\operatorname{sig} 0,002$.

2. Tidak ada pengaruh pendidikan dengan perilaku ibu hamil di Rumah Sakit Umum Daerah Simeulue Tahun 2018 dengan nilai sig 0,305.

3. Ada pengaruh sosial ekonomi dengan perilaku ibu hamil di Rumah Sakit Umum Daerah Simeulue Tahun 2018 dengan nilai sig 0,035.

4. Ada pengaruh kualitas pemeriksaan ANC dengan perilaku ibu hamil di Rumah Sakit Umum Daerah Simeulue Tahun 2018 dengan nilai sig 0,006 .

5. Tidak ada pengaruh dukungan keluarga dengan perilaku ibu hamil di Rumah Sakit Umum Daerah Simeulue Tahun 2018 dengan nilai sig 0,151.

6. Ada hubungan perilaku ibu hamil dengan berat badan bayi lahir di Rumah Sakit Umum Daerah Simeulue Tahun 2018 dengan nilai sig 0,000.

7. Faktor yang paling dominan mempengaruhi perilaku ibu hamil adalah faktor pengetahuan dengan nilai sig 0,002 dan Exp (B) sebesar 29.954 .

\section{DAFTAR PUSTAKA}

1. Angraini, DR dan Yazid S. Kupas Tuntas Seputar Kehamilan. Jakarta. AgroMedia Pustaka; 2013

2. Hayati, AW. Buku Saku Gizi Bayi. Jakarta. EGC; 2009 
3. RSUD Simeulue. Data Rekam Medik Peritanologi RSUD.2016

4. RSUD Simeulue. Data Rekam Medik Peritanologi RSUD.2017

5. Endriana. Hubungan Umur dan Paritas dengan Berat Bayi Lahir di RB Citra Insani Semarang. http://download.portalgaruda.org /article.php?article $=98424 \&$ val $=$ 422

6. Darmayanti, IP. Dkk. Buku Ajar Asuhan Kebidanan Komprehensif Pada Ibu Bersalin dan Bayi Baru Lahir. Yogyakarta. Deepublish; 2014

7. Oktaria, M. Buku Ajar Asuhan Kebidanan Persalinan dan Bayi Baru Lahir. Yogyakarta. Deepublish; 2016

8. Hayati, AW. Buku Saku Gizi Bayi. Jakarta. EGC; 2009

9. Nurdiansyah, N. Buku Pintar lbu dan Bayi. Jakarta. Bukene; 2011

10. Dinas Kesehatan Kabupaten Simeulue. Data Dinas Kesehatan Kabupaten. 2017

11. Fatonah, S. Gizi \& kesehatan untuk Ibu Hamil. Jakarta. Erlangga; 2016

12. Riyadi, ALS. Ilmu Kesehatan Masyarakat. Yogyakarta. Andi; 2016

13. Kementrian Kesehatan Republik Indonesia. Profil Kesehatan Indonesia Tahun 2015. Jakarta. Kemenkes RI; 2016

14. Profil Kesehatan Aceh 2016. Dinas Kesehatan Aceh; 2017

15. Karima, K. Status Gizi lbu dan Berat Badan Lahir Bayi. Available from https://media.neliti.com/media/p ublications/39494-ID-status-giziibu-dan-berat-badan-lahirbayi.pdf

16. Mustika, E. Hubungan Usia dan Jarak Kehamilan dengan
Kejadian Berat badan Lahir Rendah (BBLR) di RSUD Pembahan Senopati Bantul Yogyakarta. Available from : http://digilib.unisayogya.ac.id/95 5/1/Naskah\%20Publikasi.pdf

17. Mustika, E. Faktor - Faktor Ibu yang Berhubungan Dengan Kejadian Bayi Berat Lahir Rendah di RSU Jawa Barat Tahun 2015. Available from : http://digilib.unisayogya.ac.id/14 85/1/NASKAH\%20PUBLIKASI BHARYO\%20SULISTYORINI.p df

18. Hidayatush. Analisis Resiko Kejadian Bayi Berat Lahir Rendah (BBLR) pada Primigravida di Kabupaten Probolinggo Tahun 2015. Available from : https://ejournal.unair.ac.id/MGl/article/vi ew/3127/2284

19. Suryati. Faktor - Faktor yang Mempengaruhi Kejadian Bayi Berat Lahir Rendah (BBLR) di Wilayah Kerja Puskesmas Air Dingin Tahun 2013. Available from

http://jurnal.fkm.unand.ac.id/inde x.php/jkma/article/view/129/133

20. Linda. Hubungan Pertambahan Berat Badan dan Ukuran Lingkar Lengan Atas Ibu selama kehamilan dengan berat badan bayi baru lahir di puskesmas tanjung karang tahun 2012. http://jurnal.unimus.ac.id/index.p hp/jur_bid/article/download/552/ 602

21. Rahayu. Hubungan Umur Dan Paritas Dengan Kajadian Berat Badan Lahir Rendah (BBLR).

https://journal.umbjm.ac.id/index .php/healthy/article/download/64 /39/ 
22. Mahayana, AS. Faktor Risiko yang Berpengaruh terhadap Kejadian Berat Badan Lahir Rendah di RSUP Dr. M. Djamil Padang. Available from : http://jurnal.fk.unand.ac.id/index. php/jka/article/viewFile/345/300

23. Wagiyo dan Putrono. Asuhan Keperawatan Antenatal, Intranatal dan Bayi Baru Lahir Fisiologis dan Patologis. Yogyakarta. Andi; 2016

24. Dwienda R, Octa dkk. Buku Ajar Asuhan Kebidanan Neonatus, Bayi/Balita dan Anak Prasekolah Untuk Para Bidan. Yogyakarta. Deepublish; 2014

25. Armini, NW. Dkk. Asuhan Kebidanan Neonatus Bayi, Balita dan Anak Prasekolah.Yogyakarta: $\quad$ CV Andi Offset; 2017

26. Sembiring, JB. Asuhan Neonatus Bayi, Balita, Anak Pra Sekolah. Yogyakarta. Deepublish; 2017

27. Triana, A., Dkk. Buku Ajar Kegawatdaruratan Maternal dan Neonatal Penuntun Belar Mata Kuliah Asuhan Kebidanan Maternal dan Neonatal. Yogyakarta. Deepublish; 2015

28. Jitowowiyona S, dan Kristianasari W. Asuhan Keperawatan Neonatus dan Anak. Yogyakarta. Nuhamedika; 2011

29. Sudarti, F. Asuhan Kebidanan Neonatus Resiko Tinggi dan Kegawatan. Yogyakarta. Nuhamedika; 2015

30. Syahdrajad, T. Panduan Menulis Tugas Akhir Kedokteran dan Kesehatan. Jakarta. Pranada Media; 2015

31. Chomaria, N. Panduan Terlengkap Kehamilan Makanan Sehat Seimbang Bagi Ibu Hamil. Jakarta. Gramedia; 2012

32. Hutahaean, S. Perawatan Antenatal. Jakarta. Salemba Medika; 2013

33. Mardjan, H. Petunjuk Praktis EFT (emotional freedom techniques) untuk Mengatasi Kecemasan lbu Hamil. Pontianak. Abrori Institute; 2016

34. Maryam, S. Promosi Kesehatan dalam Pelayanan Kebidanan. Jakarta. EGC; 2017

35. Andy, R. Nutri Sang Buah Hati Bukti Cinta lbu Cerrdas. Yogyakarta. Gosyen Publishing; 2016

36. Peraturan Gubernur Aceh Nomor 67 tahun 2017 tentang Penetapan Upah Minimum Provinsi Aceh Tahun 2018. Available from https://docs.google.com/viewern g/viewer?url=http://jdih.acehprov .go.id/peraturangubernur/Pergub_2017/Peratura n_Gubernur_Aceh_Nomor_67_ Tahun_2017.pdf\&hl=en

37. Novita, $N$ \& Franciska, $Y$. Promosi kesehatan dalam Pelayanan Kebidanan. Jakarta: Penerbit Salemba Medika; 2013.

38. Mudammad, I. Pemanfaatan SPSS Dalam Penelitian Bidang Kesehatan dan Umum. Bandung: Citapustaka Media Perintis; $\quad 2016$ 